\title{
Analysis of land use/land cover change in Adei watershed, Central Highlands of Ethiopia
}

\author{
Megersa Olumana DINKA ${ }^{1) A B C D E F} \bowtie$, Degefa Dhuga CHAKA ${ }^{2) ~ A B C D E F ~}$
}

\footnotetext{
1) orcid.org/0000-0003-3032-7672; Department of Civil Engineering Sciences, Faculty of Engineering and the Built Environment, University of Johannesburg APK Campus, P. O. Box 524, Auckland Park 2006, Johannesburg, South Africa; e-mail:mdinka@uj.ac.za

2) Environmental Protection Department, Oromia Rural Land and Environmental Protection Bureau, Addis Ababa, Ethiopia; e-mail: dugadegef@yahoo.com
}

For citation: $\quad$ Dinka M.O., Chaka D.D. 2019. Analysis of land use/land cover change in Adei watershed, Central Highlands of Ethiopia. Journal of Water and Land Development. No. 41 (IV-VI) p. 146-153. DOI: 10.2478/jwld-2019-0038.

\begin{abstract}
Land use/land cover changes (LULCC) at Adei watershed (Ethiopia) over a period of 23 years (1986-2009) has been analysed from LANDSAT imagery and ancillary data. The patterns (magnitude and direction) of LULCC were quantified and the final land use/land cover maps were produced after a supervised classification with appropriate post-processing. Image analysis results revealed that the study area has undergone substantial LULCC, primarily a shift from natural cover into managed agro-systems, which is apparently attributed to the increasing both human and livestock pressure. Over the 23 years, the aerial coverage of forest and grass lands declined by $8.5 \%$ and $4.3 \%$, respectively. On the other hand, agricultural and shrub lands expanded by $9.1 \%$ and $3.7 \%$, respectively. This shows that most of the previously covered by forest and grass lands are mostly shifted to the rapidly expanding farm land use classes. The findings of this study suggested that the rate of LULCC over the study period, particularly deforestation due to the expansion of farmland need to be given due attention to maintain the stability and sustainability of the ecosystem.
\end{abstract}

Key words: change analysis, GIS, image analysis, land use and land cover, remote sensing

\section{INTRODUCTION}

Land use/land cover change (LULCC) is a term used for the modification of the earth terrestrial surface by humans, mostly the results of an interaction between natural and anthropogenic processes [RAWAT, KUMAR 2015; DINKA 2012]. Anthropogenic processes are the major driving force in shaping LULCC [BARLOW et al. 2016; BRUIJNZEEL 2004; ISLAM et al. 2017; RAWAT, KUMAR 2015; TSEGAYE et al. 2010] and are significantly changing the Earth surface, resulting in to an observable changing pattern in the LULC (land use/land cover) over time [BARLOW et al. 2018; DINKA 2012].

Various studies have indicated that LULCC are significantly affecting the functionality of Earth system directly or indirectly [BARLOW et al. 2016; BISIRI et al. 2017;
BRUIJNZEEL 2004; BUTT et al. 2015; CAO et al. 2017; Chase et al. 1999; Defries, EShleman 2004; DinKA 2012; FU 2003; FU et al. 2000; GAREDEW et al. 2009; ILAY, KAVDIR 2009; JIN, FAN 2018; LAMBIN et al. 2003; Liverman, Cuesta 2008; Pielke 2001; RAWAT, Kumar 2015; SERRAA et al. 2008; WANG et al. 2008; YILLIA 2008]. LULCC has different negative socio-economic and environmental consequences such as: reduction of landscape diversity and complexity [BARLOW et al. 2016; SERRAA et al. 2008]; contribute to climate change (of various scale) [CHASE et al. 1999; JIN, FAN 2018; LAMBIN et al. 2003; SERRAA et al. 2008]; an increase vulnerability of certain natural hazards (floods, droughts, fires) [ILAY, KAVDIR 2009; JIN, FAN 2018; SERRAA et al. 2008]; alters ecosystem services to human needs [LAMBIN et al. 2003]; and alters the streamflow pattern [BRUIJNZEEL 2004; BUTT 
et al. 2015; DEFRIES, ESHLEMAN 2004]. There is a nexus between LULCC, land degradation and water quality deterioration [BUTT et al. 2015; DINKA 2012; YILLIA 2008]. As indicated by TURNER et al. [2001], LULCC usually results in an increment of surface runoff, decrease of groundwater recharge and increased pollutant transfer [BUTT et al. 2015]. In general, LULCC have various consequences on Earth's ecology, hydrology, climate, geomorphology and biogeochemical cycles [BISRI et al. 2017; DINKA 2012; GAREDEW et al. 2009; GRZYWNA, SENDER 2017; LIVERMAN, CUESTA 2008; MineA, IOANA-TOROIMAC 2016; URBAŃSKI, JAKUBIAK 2017].

There are different views regarding the main deriving factor for LULCC [GAREDEW et al. 2009; LAMBIN et al. 2003; MAther, NeEdLE 2000; RAWAT, Kumar 2015]. According to MATHER and NEEDLE [2000], population growth is the single most influential for LULCC and the resulting land degradation. The study made by WANG et al. [2008] indicated socioeconomic development as the main driving force of LULC in Tibetan Plateau (China). Others scholars (GEIST and LAMBIN [2002], TOLE [2004], DHAKAL [2008] and GAREDEW et al. [2009]) suggested that LULCC is due to the combined effects of anthropogenic activities (proximate causes - such as expansion of farm land and extraction of woods) and fundamental social processes (underlying causes - such as population growth, policy/institution and cultural factors). LAMBIN et al. [2003] concluded that neither population nor poverty alone constitute the major underlying causes of LULCC worldwide. They concluded that the main driver of LULCC are peoples' responses to economic opportunities facilitated by institutional factors.

LULCC is the main source of land degradation, which results in a various hydrologic consequences (flooding, erosion, drought). In highland areas, land degradation usually results in an increased surface runoff and soil erosion. In Ethiopia, LULCC and land degradation are highly interrelated. Study report by MOEYERSONS et al. [2006] showed that deforestation and the introduction of an intensive permanent agriculture were the major causes of environmental degradation in northern Ethiopia, increasing the intensity of most of the erosion processes. Other independent studies (Hurni [1988], Constable, Belshaw [1989], Abate [1994], Ei-SwAIfy, Hurni [1996] and Zeleke [2000]) also indicated that deforestation and encroachment of cultivation in to marginal areas were the main causes of LULCC and land degradation in the highlands of Ethiopia. As a result, the northern highlands are highly degraded. The area is amongst those with high rate of deforestation and land degradation in Sub-Saharan Africa [EI-SWAIFY, HURNI 1996; GAREDEW et al. 2009] and frequently affected by drought and famine.

Analysis and detection of LULCC is extremely important for better understanding of landscape dynamic over a known time period [RAWAT, KUMAR 2015]. It is one of the most precise techniques to understand the land condition in the past, types of changes to be expected in the future, as well as the forces and processes behind the changes [DINKA 2012]. The aim of this study was to map and ana- lyse the spatio-temporal LULCC of the Adei watershed using decadal LANDSAT imagery (1986, 1995 and 2009). Three LANDSAT images were processed, classified and analysed in ERDAS Imagine (ver. 9.1). Also, appropriate image pre-processing (geo-referencing, layer-stacking, resolution merge, and sub-setting) and accuracy assessment has been made. The result of this study provides the region and policy makers with clear view of the watershed including vegetation cover, human interactions with natural resources and other information while undertaking different natural resources conservation activities in the region.

\section{STUDY AREA}

The study was carried out at Adei watershed, located in Boda Kebele, Dandi Woreda in West Shoa zone of Oromia National Regional State, Ethiopia (Fig. 1). Adei Watershed $\left(08^{\circ} 53^{\prime} 55^{\prime \prime}\right.$ to $08^{\circ} 55^{\prime} 34^{\prime \prime} \mathrm{N}$ and $38^{\circ} 07^{\prime} 62^{\prime \prime}$ to $\left.38^{\circ} 13^{\prime} 16^{\prime \prime} \mathrm{E}\right)$ is located at a distance of $20 \mathrm{~km}$ South-West of Ginchi town and about $110 \mathrm{~km}$ to the West of Addis Ababa. It has a total area of 2,176 ha and elevation in the range 2,180 to $3,155 \mathrm{~m}$ a.s.l. The watershed is characterized by different landforms: flat plains, undulating plains, rolling land and steep areas. About $28 \%$ of the total area has gentle slope $(<8 \%)$; whereas $35 \%$ and $37 \%$ of the total areas are characterized as moderate $(8-15 \%)$ and steep (>18\%) slopes, respectively [CHEKUN 2002]. As the result, the study area is generally exposed to soil erosion. The area is dominantly contains black soil: Pellic Vertisols (46\%), Vertic Cambisols (42\%), and Nitosols (12\%) [DWARDO 2011]. The area has a mean annual rainfall of $750-2153 \mathrm{~mm}$ and the mean annual temperature of 9.3$23.0^{\circ} \mathrm{C}$ [EMA 2013]. The total population of the watershed is about 1,945 (845 male and 1,100 female). There are diverse land use practices in the area: cultivated land (58\%), forest $(10 \%)$, grazing $(16 \%)$, shrub, villages and degraded areas $(15 \%)$. The predominant source of the community's livelihood is subsistence agriculture with the major crops grown includes teff, wheat, and barley, which constitute $80.2 \%$ of area covered by crops. Beans and maize are also grown in the area next to the major crops [DWARDO 2011].

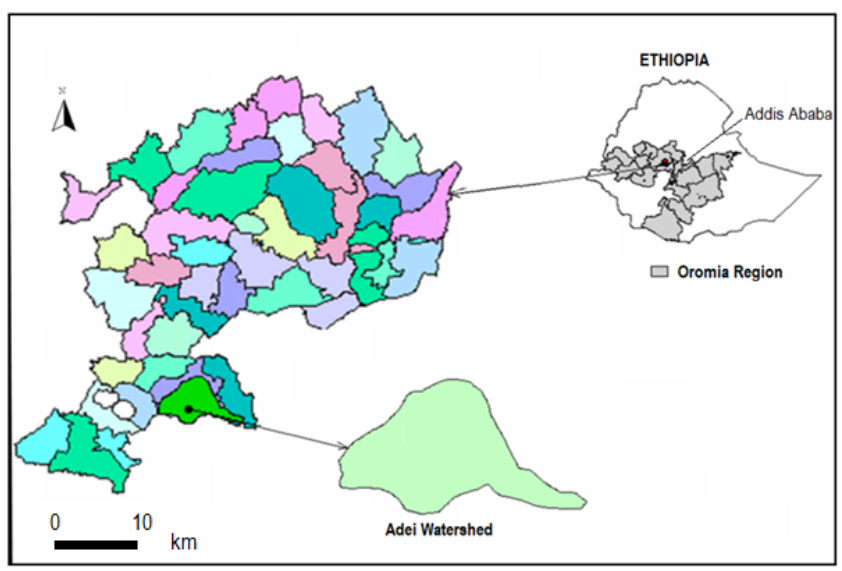

Fig. 1. Location map of the study area; source: own elaboration 


\section{STUDY METHODS}

\section{DATA ACQUISITION AND PRE-PROCESSING}

In this study, both primary and secondary data were collected. Primary data were generated from the analysis of satellite images and preliminary field survey using handheld GPS. Three LANDSAT images covering different periods (1986 TM, $1995 \mathrm{ETM}+$ and $2009 \mathrm{ETM}+$ ) were acquired from GLOVIS website (http://glovis.usgs.gov). Details (path/row, cloud cover, resolution and acquisition time) of the satellite images are provided in Table 1. The three images were selected by considering the period of change in regime government and land/use cover reforms made in Ethiopia. Moreover, field data collection was made (2012-2013) to identify the actual LULC available in the study area. Field investigation was required to take the representative ground control points (GCPs) from each of the currently identified land use types. The GCPs were used for the preparation of signatures for supervised classification. Secondary data such as Digital Elevation Model (DEM) and topographic maps were collected from different sources. The DEM with $90 \mathrm{~m}$ resolution was downloaded from NASA website (http://www2.jpl.nasa.gov/ $\mathrm{srtm} /$ ) and processed in ArcGIS (v 9.3) [ESRI 2009]. The DEM sink filling, resolution merge, etc. has been done in ArcGIS. The recent (2012) Dendi Woreda topo sheet (scale 1:50 000) was purchased from the Ethiopian Mapping Agency and used for the selection of training sites and georeferencing process.

Table 1. Details of satellite data acquisition

\begin{tabular}{|l|c|c|c|c|}
\hline \multicolumn{1}{|c|}{ Sensor } & $\begin{array}{c}\text { Path/ } \\
\text { Row }\end{array}$ & $\begin{array}{c}\text { Cloud } \\
\text { cover }(\%)\end{array}$ & $\begin{array}{c}\text { Resolution } \\
\text { (pixel size) }\end{array}$ & $\begin{array}{c}\text { Acquisition } \\
\text { time }\end{array}$ \\
\hline Landsat - TM & $168 / 54$ & 0 & $30 \times 30 \mathrm{~m}$ & Feb, 1986 \\
\hline Landsat - ETM+ & $168 / 54$ & 0 & $28.5 \times 28.5 \mathrm{~m}$ & Jan, 1995 \\
\hline Landsat - ETM+ & $186 / 54$ & 0 & $28.5 \times 28.5 \mathrm{~m}$ & Mar, 2009 \\
\hline
\end{tabular}

Source: own elaboration.

Digital satellite images were processed, classified and analysed by ERDAS Imagine (ver. 9.1) [ERDAS 2006]. The classified data (in to each category of LULC) was further analysed for change detection of degraded/bare land. An intensive pre-processing such as geo-referencing, layerstacking, resolution merge, and sub-setting were carried out in order to Ortho-rectify the satellite images in to Universal Transverse Mercator (UTM) (WGS, 1984) (coordinates -WGS 37N; Spheoid - Clarke 1880; and datum Adindum) and to remove disturbances and radiometric variation between acquisition dates [DINKA 2012]. The satellite image of each band in each year (1986, 1995 and 2009) was stacked in ERDAS Imagine (ver. 9.1) within interpreter main icon utilities with layer stacked function. Preliminary image analysis was done using ERDAS to extract meaningful information from the acquired satellite images.

\section{SATELLITE IMAGE PROCESSING}

In this study, a hybrid classification system has been used, which involves the unsupervised classification followed by supervised classification methods. Unsupervised classification was preferred for classification of all Landsat imagery and to obtain a signature for supervised classification. A set of spectral classes were formed and a map pattern was visually correlated to meaningful ground categories or land cover classes, according to the descriptions presented in Table 2. Then, a natural cluster comprised of twenty different classes was created using the ISODATA (Iterative Self-Organizing Data Analysis Technique) algorithm, with the maximum number of iteration set to ten at 95\% confidence level [SIERRA-SOLER et al. 2015]. The signatures obtained from unsupervised classification were aggregated into land cover classes and the unidentifiable clusters were rejected from the signature categorization. Then, the easily identifiable classes were categorized into land cover units to create appropriate signatures for the supervised classification [DINKA 2012; JENSEN 2005].

Table 2. Characteristics of land cover classes identification in Adei watershed

\begin{tabular}{|l|l|}
\hline Class name & \multicolumn{1}{c|}{ Description } \\
\hline Farmlands & $\begin{array}{l}\text { Areas used for crop cultivation (teff, wheat, barley, etc.) } \\
\text { and different settlements (villages) associated with the } \\
\text { cultivated fields }\end{array}$ \\
\hline Forestlands & $\begin{array}{l}\text { Areas covered with dense growth of trees that form near- } \\
\text { ly-closed canopies ( }>40 \% \text { ). Some trees (mainly eucalypts } \\
\text { \& acacia) commonly found around homesteads were } \\
\text { included in this category }\end{array}$ \\
\hline Grasslands & $\begin{array}{l}\text { Areas used for grazing as well as bare lands (or rocks) } \\
\text { with little or no grass cover }\end{array}$ \\
\hline Shrublands & $\begin{array}{l}\text { Refers to those areas covered with tree, shrub, bushes and } \\
\text { some grasses that dominate the foot slopes and riverine } \\
\text { landscapes. There exists variation in vegetation between } \\
\text { dense shrub/bush lands with an estimated cover of }>50 \% \\
\text { and open shrub/bush lands with less than 50\% cover }\end{array}$ \\
\hline
\end{tabular}

Source: own elaboration based on Ahmed's classification [AHMAD [2012].

In order to define classes that were not uniquely identified during the unsupervised classification, an addition signatures were defined on the AOI (area of interest) for known cover types from field data and the topo-map. The final signatures were demarcated after a series of band combinations (by trial and error procedure) and used for the supervised classification. Finally, the images were classified through maximum-likelihood parametric decision rule with probabilities approach and parallellopide as the non-parametric decision rule [DINKA 2012; JENSEN 2005].

Based on the GCPs points the classified LULC using supervised classification were cross checked with the ground truth. This was done by the use of accuracy assessment technique to investigate how the result reflects the reality on the ground [SHAO, WU 2008]. This was done by the use of GCPs collected during the field work. The accuracy of the classification was assessed by using four per- 
formance assessment criteria: producer's accuracy $(P A)$, user's accuracy $(U A)$, overall accuracy $(O A)$ and Kappa coefficient $(K)$. An error matrix which comprises $O A, U A$, $P A$ and $K$ was generated for the identified LULC types.

\section{POST-PROCESSING AND CHANGE ANALYSIS}

After supervised classification, appropriate postprocessing has been done. Majority analysis was applied in order to avoid minor fragmented classification arrangements on the output map. The majority analysis (such as clump, sieve and filtering) [DINKA 2012] was repeated four times until fine classification are removed. The simple approach consists of comparing the properly coded results of two separate classifications [MANANDHAR et al. 2009]. Finally, the final classification was verified using GCPs in order to check the precision of the classified LULC map. Evaluation of LULC change analysis through pair-wise comparison and weighted overlay was carried out in the Arc GIS 9.3 environment. Based on the ground verifications, the necessary corrections and adjustments has been done. Finally, a complete confusion matrix of categorical change was obtained for the 2009 image.

In order to analyse the land cover structural changes in the study area, the table showing the area in hectares and percentage changes between the periods 1986-1995 and 1995-2009 was quantified for each LULC types. The absolute change in LULC of the two periods was obtained as the difference of the values of different times of the same category while percentage change was calculated by dividing it with the total area and multiplying by hundred. This provided the information on the trend of conversion in terms of time. Finally, the areal coverage, annual rate of change, change rate and relative change were tabulated for each of the identified LULC types. The annual change rates were calculated using Eq. (1) [DINKA 2012; ETTER et al. 2006]:

$$
\text { Rate }=\frac{1}{\left(t_{2}-t_{1}\right)} \ln \left(\frac{A_{2}}{A_{1}}\right)
$$

Where: $A_{1}$ and $A_{2}$ are forest cover at initial $\left(t_{1}\right)$ and next time step $\left(t_{2}\right)$, respectively.

\section{RESULTS AND DISCUSSIONS}

\section{LULC CHANGE ANALYSIS}

The classification assessment report is summarized in Table 3. The result showed that UA of individual class ranged from $73-88 \%$, while $P A$ ranged from $64-95 \%$.
Lower $P A$ was observed for grasslands (64\%) only, which might have occurred due to the combination of omission and commission errors. The resulting lower accuracy for grazing land might be due to the difficulty to identify grass land from farm land on the image and its low ground cover condition [DINKA 2010; 2012]. The resulting LULC map had an acceptable $O A(82 \%)$ and $K(0.76)$, indicating a good agreement between the reference data and the remotely sensed classification [SHAO, WU 2008]. The obtained individual $K$ value is different for the different land cover types, with the highest value for shrubs, followed by farm, forest and grazing lands. Overall, the accuracy assessment results are acceptable for further analysis and change detection. As illustrated in Figures 3-4, four LULC classes (farm, forest, grass, and shrub) were identified after a supervised classification.

Table 3. Summary of confusion matrix for the Landsat $\mathrm{ETM}^{+}$ image (2009)

\begin{tabular}{|l|c|c|c|c|c|c|}
\hline Land cover & \multirow{2}{*}{$\begin{array}{c}\text { Classified } \\
\text { class }\end{array}$} & \multirow{2}{*}{$\begin{array}{c}\text { Number } \\
\text { totals }\end{array}$} & Numbers & Nuls & correct & \multicolumn{3}{|c|}{ Accuracy (\%) } \\
\cline { 5 - 8 } & & $k^{\prime}$ & PA & UA \\
\hline Forestlands & 26 & 20 & 19 & 0.738 & 95 & 73 \\
\hline Farmlands & 38 & 40 & 33 & 0.868 & 83 & 87 \\
\hline Grasslands & 11 & 14 & 9 & 0.818 & 64 & 82 \\
\hline Shrublands & 8 & 9 & 7 & 0.875 & 78 & 88 \\
\hline Total & 83 & 83 & 68 & & & \\
\hline
\end{tabular}

Overall accuracy $(O A)=82 \%$.

Overall Kappa coefficient $(K)=0.76$.

Explanations: $k^{\prime}=$ classical Kappa statistics; $P A=$ producer accuracy; $U A=$ user accuracy.

Source: own study.

The land use trend analysis made for two periods (1986-1995 and 1995-2009) indicates that Adei watershed was subjected to considerable land use changes. Rate of temporal change of LULC in Adei watershed over the period of 1986-2009 is presented in Table 4. Under this section, the LULC dynamics in different periods are presented, by giving more attention to the effects of population pressure and institutional support on LULCC.

\section{- Period 1: 1985 to 1995}

During this period, the areal coverage of forest and shrub lands were decreased by 201.9 ha $(9.3 \%)$ and 49.4 ha (2.3\%), respectively. On the other hand, both farm and grass lands have increased by an aerial coverage of 59.60 ha $(2.70 \%)$ and 191.40 ha $(8.80 \%)$, respectively. This was due to the conversion of forest and shrub lands, to grass and farm lands. As evident from Figure 2, farm lands were increased during this period at the expense of all the other 3 LULC types, but mostly at the expense of grazing lands.

Table 4. Rate of temporal change of land use/land cover (LULC) in Adei watershed over the period of 1986-2009

\begin{tabular}{|c|c|c|c|c|c|c|c|c|c|c|c|c|c|c|c|}
\hline \multirow{3}{*}{$\begin{array}{l}\text { LULC } \\
\text { class }\end{array}$} & \multicolumn{6}{|c|}{ Area } & \multicolumn{3}{|c|}{ Net change (ha) } & \multicolumn{3}{|c|}{ Change $(\%)$} & \multicolumn{3}{|c|}{ Rate of change (ha'year $\left.{ }^{-1}\right)$} \\
\hline & \multicolumn{2}{|c|}{1986} & \multicolumn{2}{|c|}{1995} & \multicolumn{2}{|c|}{2009} & \multirow{2}{*}{$\begin{array}{c}1986- \\
1995\end{array}$} & \multirow{2}{*}{$\begin{array}{c}1995- \\
2009\end{array}$} & \multirow{2}{*}{$\begin{array}{c}1986- \\
2009\end{array}$} & \multirow{2}{*}{$\begin{array}{c}1986- \\
1995\end{array}$} & \multirow{2}{*}{$\begin{array}{c}1995- \\
2009\end{array}$} & \multirow{2}{*}{$\begin{array}{c}1986- \\
2009\end{array}$} & \multirow{2}{*}{$\begin{array}{c}1986- \\
1995\end{array}$} & \multirow{2}{*}{$\begin{array}{c}1995- \\
2009\end{array}$} & \multirow{2}{*}{$\begin{array}{l}1986- \\
2009\end{array}$} \\
\hline & (ha) & $(\%)$ & (ha) & $(\%)$ & (ha) & $(\%)$ & & & & & & & & & \\
\hline Farms & 818.2 & 37.6 & 877.8 & 40.30 & 1015.4 & 46.70 & 59.60 & 137.60 & 197.30 & 2.70 & 6.30 & 9.10 & 6.60 & 9.80 & 16.50 \\
\hline Forest & 552.8 & 25.4 & 350.8 & 16.10 & 367.6 & 16.90 & -201.90 & 16.80 & -185.20 & -9.30 & 0.80 & -8.50 & -22.40 & 1.20 & -21.20 \\
\hline Grass & 463.6 & 21.3 & 655.0 & 30.10 & 370.9 & 17.00 & 191.40 & -284.10 & -92.70 & 8.80 & -13.10 & -4.30 & 21.30 & -20.29 & -10.30 \\
\hline Shrub & 341.4 & 15.7 & 292.0 & 13.40 & 421.7 & 19.40 & -49.40 & 129.70 & 80.30 & -2.30 & 6.00 & 3.70 & -5.50 & 9.26 & 3.80 \\
\hline
\end{tabular}

Source: own study. 


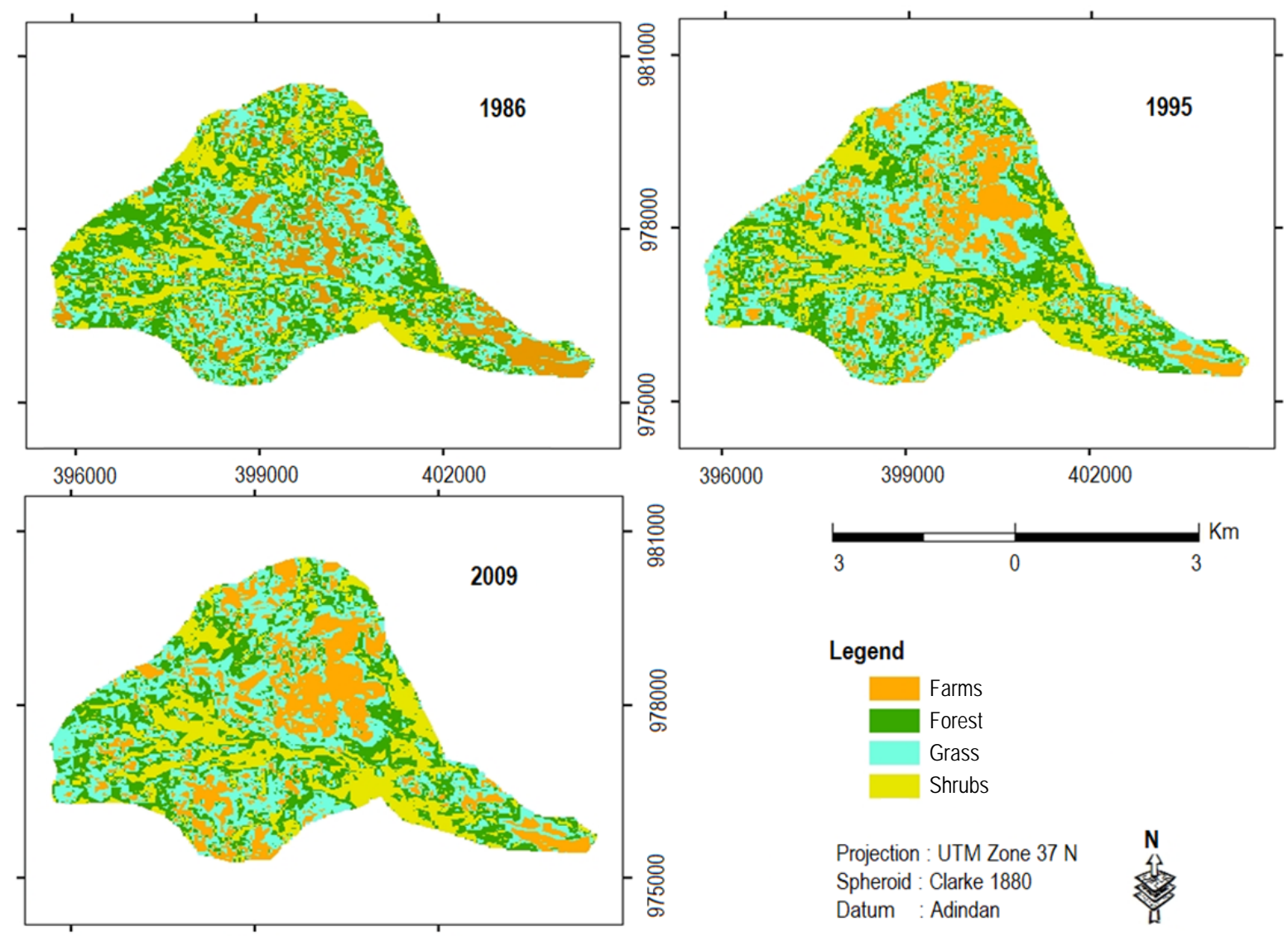

Fig. 2. Classified land use/cover types in the study area; source: own study

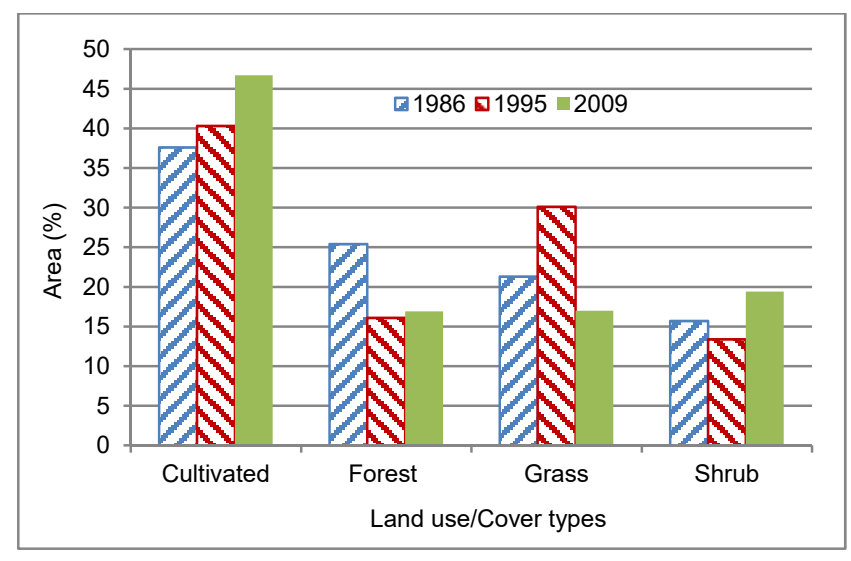

Fig. 3. Area coverage of the classified land use/cover types; source: own study

Furthermore, grazing lands were increased at the expense of shrub and forestlands.

The early stage of this study period was considered as the time of intensive government intervention and there was due attention for improved land use and natural resources management, particularly forest management activities. There was a law by which farmers were prohibited from cutting trees whether for housing or charcoal purposes. The area was covered by different indigenous tree species and there was no pressure on natural resources since the area has fertile land for crop production. Hence, farmers had no interest to expand their farmlands as well as encroach to more fragile and forest covered areas.
But at the nearly last stage of this period, both forest and shrub lands decreased in area coverage. The last stage of this period was few years after the Ethiopian government transition period (i.e downfall of Derg ${ }^{1)}$ regime), when larger areas of communal land was distributed among community members and other landless peoples in the area. In addition to this, the laws and policies were not as strong as before, especially during the early stage of the existing government, whereby people started to clear forests to expand their farm land areas to increase food production. Consequently, there was a rapid conversion of natural forest covered area to farm lands. Moreover, pocket areas covered by forest and shrub lands were shifted to grazing land and became degraded. This resulted in decline in forest coverage and expansion of farm land in the area.

\section{- Period 2: 1995-2009}

Conversely to the preceding period (1985-1995), forest and shrub lands showed an increment in this period. But a significant increment was observed in farmland $(6.3 \%)$. That means all the 3 LULC types were increased in this period at the expense of grass lands. During this period, the decrease in grass land by 284.10 ha $(13.1 \%)$ is equal to the total increase of the other 3 LULC types $(13.1 \%)$ - Table 4 . The increment in farm and forest lands

\footnotetext{
1) 'Derg' or Dergue refers to the short name of the Coordinating Committee of the Armed Forces, Police and Territorial Army that ruled Ethiopia from 1974 to 1987. The period is also called 'Mengistu Regime Government'.
} 
in this period is due to the improved governments' strategies and guidelines on the rural development policies, which gave due attention to natural resources management based on participatory and integrated watershed management approach. There was a good involvement of rural community (i.e participatory watershed management approach), non-governmental organizations and other concerned bodies for the rehabilitation (i.e both reforestation and afforestation) of previously degraded areas as well as conservation of potential areas. The local community started to practice some soil and water conservation activities, area closure system as well as planting of different tree and acacia species from the established nursery sites. Seedlings of different tree species from the nurseries were distributed by government and different non-governmental organizations, particularly by GTZ (German Technical Cooperation Agency).

\section{GENERAL DISCUSSION}

The LULC showed spatio-temporal dynamics (Tab. 4, Figs. 2-3) throughout the study period (1986-2009). Farm land showed high (increased) rate of change followed by farm, grass and shrub lands. Both grass and forest lands showed a declining trend; whereas farm and shrub lands showed an increasing trend. There is a sharp annual increment rate in areas of farm land (16.5 ha) and slight annual increment rate in shrub land (3.8 ha), which showed that forests changed to shrub land and then gradually to farm land. On the other hand, forest and grass lands have fallen by an aerial coverage of about 185.19 and 92.73 ha (Tab. 4, Fig. 4), respectively. The expansion of farm land was almost at the expense of grass and forest lands. The study conducted by EMIRU et al. [2012] on Senbat watershed (Ethiopia) in 1957-1980 showed a massive deforestation (47\% reduction) in favour of the expansion of farm lands, largely due to an expansion of agricultural and livestock production activities. Similarly, a study made by DINKA [2012] for Lake Basaka catchment indicates that forest coverage reduced from $42.2 \%$ in the early 1960 s to only $6 \%$ in 2008 . This study and other study results are indicators for the massive deforestation in Ethiopia in general. All studies indicated that there is rapid conversion of forest covered area to cultivated land.

The decreasing rate of forest, grass and shrub lands obtained in this study has an implication on land degradation,

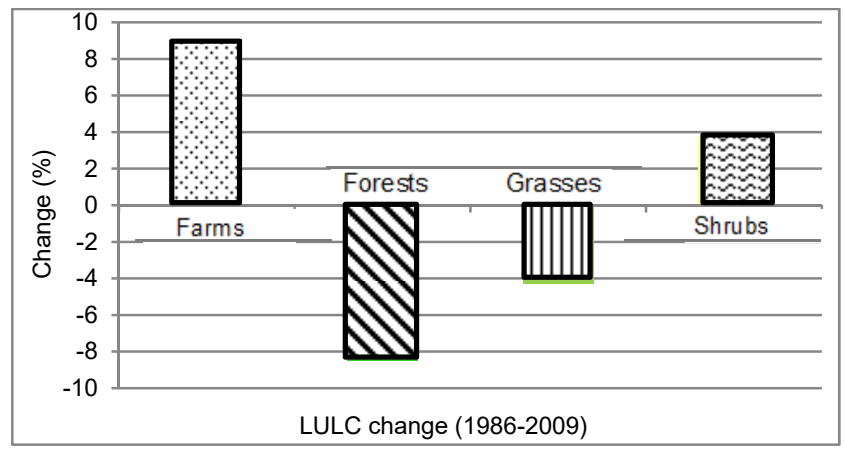

Fig. 4. Land use/land cover change (LULCC) of the study area over study period; source: own study particularly soil erosion and decline of crop yield in the area. Different studies (BRUIJNZEEL [2004], SERRA et al. [2008], GAREDEW et al. [2009], ILAY, KAVDIR [2009], DINKA [2012] and EMIRU et al. [2012]) clearly showed that surface erosion is minimal in those areas where the soil is adequately protected or areas covered by vegetation. The presence of these resources on the surface of the earth has two important roles [DINKA 2012]: (i) it reduces the impact of rain drops on the surface of the earth and minimizes the wearing away off top soil by erosion; and (ii) increases the infiltration capacity of the soil and caused to recharge the ground water. So the reduction of those resources has aggravated land degradation.

According to HURNI [1988; 1993], the most important factors deriving LULCC in Ethiopia is population growth. Based on the findings of this study, the authors support the idea suggested by LAMBIN et al. [2003]. The main anthropogenic drivers of LULCC in the study area are population growth facilitated by economic (poverty) and institutional factors. As population and poverty increases, specifically in the highland areas, the need for more cultivated lands, grazing area, and fuel woods also increased to meet the growing demand for food, energy and livestock. More and more marginal lands are being used for agriculture. This agricultural intensification has led to a rapid natural resources degradation, which manifests itself mainly on the soil layers which has been already eroded and nutrients have been continuously removed. The effect of institutional support on LULC dynamics can be realized from Table 4, which was discussed earlier under section LULC change analysis. In general, in Ethiopian highlands, an urgent intervention is needed to address the problem of land degradation using suitable technologies for improved and sustainable agricultural production [TADESSE, BELAY 2004].

\section{CONCLUSIONS AND RECOMMENDATIONS}

In Adei watershed, the ecosystem was more or less protected before the intervention by human (1970s); like forest clearance, overgrazing and expansion of cultivated lands. The 1986 image clearly indicates that the area was rich in vegetation cover with $25.40 \%$ forest and $21.30 \%$ grass lands. All the identified land use/land cover (LULC) types have undergone both spatial and temporal changes over 23 years (1986-2009): sharp decrement for forest $(8.5 \%)$ and grass $(4.3 \%)$ lands and increment for farm $(9.1 \%)$ and shrubs (3.7\%) lands. Various forest and grazing lands were changed to agricultural lands following the change of land use policy in Ethiopia in the 1970s for food self-sufficiency. Consequently, there was a significant shifting of natural vegetation areas to agricultural, grazing and other land use types.

The main anthropogenic drivers of LULC change in the watershed are population growth, poverty, and lack of strong institutional and technological support. Most of the changes in the watershed are largely due to an increase in agricultural production activities for food self-sufficiency. Lack of strong LULC policies and lack of technologies that suit farmers' socio-economic and natural circumstances were major driving forces behind. The LULC dynamics in 
the watershed is influencing the hydrologic processes within the watershed by disturbing both ecological and environmental nature of the watershed.

In general, the expansion of agricultural land is at high rate, causing formation of erosion prone areas highly susceptible to soil erosion. Improvement of present agricultural and livestock management practices and introduction of appropriate soil conservation measures are essential for mitigating erosion and for improving the welfare of the community in the watershed. The cultivation practice, in the study area, is mainly dependent on a traditional rain fed agriculture, and the livestock are fed entirely on natural grassland. If this condition is allowed to continue in similar manner in the feature, land degradation can put the sustainability of agriculture and availability of natural resources in the area at a great risk. There may be a similar change expected in the future which can be a major cause of land degradation in the watershed, leading to decline in crop production as well as shortage of forage for livestock; unless there is due considerations for natural resources conservation practices.

\section{REFERENCES}

ABATE S. 1994. Landuse dynamics soil degradation and potential for sustainable use in Metu Area, Illubabur Region, Ethiopia. African Studies Series. A13. Berne. University of Berne. ISBN 3906290956 pp. 135.

AHMAD F. 2012. Detection of change in vegetation cover using multi-spectral and multi-temporal information for District Sargodha, Pakistan. Sociedade Natureza. Vol. 24 p. 557-572.

Barlow J., Lennox G.D., Ferreira J., Berenguer E., Lees A.C., Mac Nally R., Gardner A.T. 2016. Anthropogenic disturbance in tropical forests can double biodiversity loss from deforestation. Nature. Vol. 535. Iss. 7610 p. 144-147.

BisRi M., Limantara L.M., Prasetyorini L., Chasanawati D. 2017. Application of the Kineros model for predicting the effect of land use on the surface run-off. Case study in Brantas subwatershed, Klojen District, Malang City, East Java Province of Indonesia. Journal of Water and Land Development. No. 35 p. 3-9.

BRUIJNZEEL L.A. 2004. Hydrological functions of tropical forests: not seeing the soil for the trees.Agriculture, Ecosystems and Environment. Vol. 104. Iss. 1 p. 185-228.

Butt A., Shabbir R., Ahmad S.S., Aziz N. 2015. Land use change mapping and analysis using Remote Sensing and GIS: A case study of Simly watershed, Islamabad, Pakistan. The Egyptian Journal of Remote Sensing and Space Sciences. Vol. 18 p. 251-259.

CaO H., LiU J., Fu C., Zhang W., Wang G., Yang G., LuO L. 2017. Urban expansion and its impact on the land use pattern in Xishuangbanna since the reform and opening up of China. Remote Sensing. Vol. 9. Iss. 2. DOI 10.3390/rs9020137.

Chase T.N., Pielke R.A., Kittel T.G.F., Nemani R.R., RunNING S.W. 1999. Simulated impacts of historical land cover changes on global climate in northern winter. Climate Dynamics. Vol. 16 p. 93-105.

CheKun T. 2002. Vetiver in the rehabilitation of the degraded areas in Ethiopia. Project Report. Addis Ababa, Ethiopia. Coffee and Tea Authority p. 131-136.

Constable M., Belshaw D. 1986. The Ethiopian Highland reclamation study: Major findings and recommendations. In: Towards a food and nutrition strategy for Ethiopia. Workshop
Proceeding. 8-12.12.1986 Alemaya, Ethiopia. University of Agriculture p. 8-12.

DEFRIES R., ESHLEMAN N.K. 2004. Land-use change and hydrologic processes: A major focus for future. Journal of Hydrological Processes. Vol. 18 p. 2183-2186.

DHAKAL M. 2008. Roger sands, forestry in a global context. Forest Policy and Economics. Vol. 10 p. 428-429.

DINKA M.O. 2010 Analyzing the extent of Basaka Lake expansion and soil and water quality status of Matahara irrigation scheme, Awash Basin (Ethiopia). PhD Thesis. Vienna, Austria. University of Natural Resources and Life Sciences pp. 241.

DiNKA M.O. 2012. Analysing decadal land use/cover dynamics of the Lake Basaka catchment (Main Ethiopian Rift) using LANDSAT imagery and GIS. Lake and Reservoirs: Research and Management. Vol. 17 p. 11-24.

DWARDO 2011. Socioeconomic and geographical profile of Dendi District. Dendi, Ethiopia. Dendi Woreda Administration and Rural Development Office pp. 198.

El-Swaify S.A., HuRNi H. 1996. Transe-boundary effect of soil erosion and conservation in the Nile Basin. Land Husbandry. Vol. 1 p. 6-21.

Emiru N., Gebrekidan H., Tibebe D. 2012. Analysis of land use/land cover changes in western Ethiopian mixed croplivestock systems: The case of Senbat watershed. Journal of Biological and Environmental Science. Vol. 2. Iss. 3 p. 8-17.

ENMA 2013. Meteorological report by the Ethiopian National Meteorological Agency. Addis Ababa, Ethiopia. Ethiopian National Meteorological Agency pp. 76.

ERDAS 2006. ERDAS field guide. 5th ed. Atlanta, Georgia. Earth Resources Data Analysis System, Inc. pp. 671.

ESRI 2009. ArcGIS Desktop Help 9.3 [online]. Redlands. Environmental Systems Research Institute, Inc. [Access 15.10.2012]. Available at: http://webhelp.esri.com/ arcgisdesktop/9.3

Etter A., McAlpine C., Wilson K., Phinn S., Passingham H. 2006. Regional patterns of agricultural land use and deforestation in Colombia. Agriculture Ecosystem and Environment. Vol. 114 p. 369-386.

Fu B., Chen L., Ma K., Zhou H., Wang J. 2000. The relationships between land use and soil conditions in the hilly area of the loess plateau in northern Shaanxi, China. CATENA. Vol. 39. Iss. 1 p. 69-79.

FU C. 2003. Potential impacts of human-induced land cover change on East Asian Monsoon. Global Planetary Change. Vol. 37 p. 219-229.

Garedew E., Sandewall M., Söderberg U., Campbell B.M. 2009. Land-use and land-cover dynamics in the Central Rift Valley of Ethiopia. Environmental Management. Vol. 44 p. 683-694. DOI 10.1007/s00267-009-9355-Z

Geist H.J., LAmBIN E.F. 2002. Proximate causes and underlying driving forces of tropical deforestation: tropical forests are disappearing as the result of many pressures, both local and regional, acting in various combinations in different geographical locations. BioScience. Vol. 52(2) p. 143-150.

GRZYWNA A., SENDER J. 2017. Land cover changes in catchment areas of lakes situated in headwaters of the Tyśmienica River. Journal of Water and Land Development. No. 33 p. 65-71.

HURNI H. 1988. Degradation and conservation of the resources in the Ethiopian Highlands. Mountain Research and Development. Vol. 8. Iss. 23 p. 123-130.

HURNI H. 1993. Land degradation, famine, and land resource scenarios in Ethiopia. In: World soil erosion and conservation. Cambridge studies in applied ecology and resource management. Ed. D. Pimentel. Cambridge, UK. Cambridge University Press p. 27-61. 
ILAY R., KAVDIR Y. 2009. Impact of land cover types on soil aggregate stability and erodibility. Environmental Monitoring Assessment. No. 190 pp. 525. DOI 10.1007/s10661-0186847-4.

IsLAM K., Jashimuddin M., NATH B., NATH T.P. 2017. Land use classification and change detection by using multi-temporal remotely sensed imagery: The case of Chunati wildlife sanctuary, Bangladesh. The Egyptian Journal of Remote Sensing and Space Sciences. Vol. 21. Iss. 1 p. 37-47. DOI 10.1016/ j.ejrs.2016.12.005.

JENSEN J.R. 2005. Introductory digital image processing: A remote sensing perspective. 3rd ed. Prentice Hall Series in Geographic Information Science. Prentice-Hall. ISBN 13:9780131453616 p. 505-512.

JIN Y., FAN H. 2018. Land use/land cover change and its impacts on protected areas in Mengla County, Xishuangbanna, Southwest China. Environmental Monitoring and Assessment. Vol. 190 (9): 509. DOI 10.1007/s10661-018-6891-0.

LAMBIN E.F., GeIST H.J., LePERS E. 2003. Dynamics of land-use and land-cover change in tropical regions. Annual Review of Environmental Research. Vol. 28 p. 205-241.

Liverman D.M., Cuesta R.M.R. 2008. Human interactions with the Earth system: People and pixels revisited. Earth Surface Processes and Landforms. Vol. 33 p. 458-1471.

Manandhar R., Odeh I.O.A., ANCEV T. 2009. Improving the accuracy of land use and land cover classification of Landsat data using post-classification enhancement. Remote Sensing. Vol. 1 p. 33-44.

Mather A.S., NeEdle C.L. 2000. The relationships of population and forest trends. The Geographical Journal. Vol. 166 p. 2-13.

Minea G., IOANA-ToroimaC G. 2016. Land use impact on overland flow: Micro-scale field experimental analysis. Journal of Water and Land Development. No. 29 p. 67-74. DOI 10.1515/jwld-2016-0013.

Moeyersons J., Nyssen J., Poesen J., Deckers J., Haile M. 2006. Age and backfill/overfill stratigraphy of two tufa dams, Tigray Highlands, Ethiopia: Evidence for Late Pleistocene and Holocene wet conditions. Palaeogeography, Palaeoclimatology, Palaeoecology. Vol. 230. Iss. 1/2 p. 162-178.

PielKE R.A. 2001. Influence of the spatial distribution of vegetation and soils on the prediction of cumulus convective rainfall. Reviews of Geophysics. Vol. 39. Iss. 2 p. 151-77.

RaWAT J.S., Kumar M. 2015. Monitoring land use/cover change using remote sensing and GIS techniques: A case study of Hawalbagh block, district Almora, Uttarakhand, India. The
Egyptian Journal of Remote Sensing and Space Science. Vol. 18 p. $77-84$.

Serraa P., Ponsa, X., Saur D. 2008. Land-cover and land-use change in a Mediterranean landscape: A spatial analysis of driving forces integrating biophysical and human factors. Applied Geography. Vol. 28 p. 189-209.

SHAO G., WU J. 2008. On the accuracy of landscape pattern analysis using remote sensing data. Landscape Ecology. Vol. 23 p. 5-11.

Shetty A., Nandagiri L., Thoкchom S., Rajesh S.M. 2005. Land use - land cover mapping using satellite data for forested watershed, Usupi District, Karnataka, India. Journal of the Indian Society of Remote Sensing. Vol. 33. Iss. 2 p. 233-238.

Sierra-Soler A., Adamowski J., Qi Z., SaAdat H., Pingale S. 2015. High accuracy Land Use Land Cover (LULC) maps for detecting agricultural drought effects in rainfed agroecosystems in central Mexico. Journal of Water and Land Development. No. 26 p. 19-35. DOI 10.1515/jwld-20150014.

TADESSE M., BELAY K. 2004. Factors influencing adoption of soil conservation measures in southern Ethiopia: The case of Gununno area. Agriculture and Rural Development. Vol. 105 p. 49-62.

TOLE L. 2004. A quantitative investigation of the population-land inequality-land clearance nexus. Population and Environment. Vol. 26 p. $75-106$.

Tsegaye D., Moea S.R., VedeldC P., Aynekulu E. 2010. Landuse/cover dynamics in Northern Afar rangelands, Ethiopia. Agriculture, Ecosystems and Environment. Vol. 139 p. 174180.

TURNer M.G., GARDNER R.H., O'NeILl R.V. 2001. Landscape ecology in theory and practice pattern and process. New York. Springer Verlag. ISBN 978-0-387-21694-2 pp. 406.

URBAŃSKI K., JAKUBIAK M. 2017. Impact of land use on soils microbial activity. Journal of Water and Land Development. No. 35 p. 249-257. DOI 10.1515/jwld-2017-0091.

WANG X., ZHeng D., Shen Y. 2008. Land use change and its driving forces on the Tibetan Plateau during 1990-2000. CATENA. Vol. 72 p. 56-66.

YILLIA P.T. 2008. Linking land use to stream pollution pollutant dynamics and management implications. PhD Thesis. Vienna, Austria. Vienna University of Technology.

ZELEKE G. 2000. Landscape dynamics and soil erosion process modelling in the north-western Ethiopian Highlands. Geographica Bernensia. African Studies Ser. A 16. Berne, Switzerland. ISBN 3906151476 pp. 201.

\section{Megersa Olumana DINKA, Degefa Dhuga CHAKA}

\section{Analiza użytkowania i pokrycia terenu w zlewni Adei na Wyżynie Centralnej w Etiopii}

\section{STRESZCZENIE}

Zmiany użytkowania i sposobu pokrycia terenu w zlewni Adei (Etiopia) analizowano w ciągu 23 lat (1986-2009) z użyciem obrazów LANDSAT i dodatkowych danych. Oceniono ilościowo schemat zmian (wielkość i kierunek) oraz wykonano mapy użytkowania i pokrycia terenu po odpowiednim przetworzeniu danych. Analiza obrazów ujawniła, że badany obszar podlegał znaczącym zmianom - głównie od naturalnego pokrycia do gospodarczych agrosystemów, co wynikało z rosnącej presji ze strony człowieka i zwierząt gospodarskich. W ciągu 23 lat powierzchnie leśne i trawiaste zmalały odpowiednio o 8,5 i 4,3\%, a powierzchnie użytkowane rolniczo i tereny zakrzaczone powiększyły się odpowiednio o 9,1 i 3,7\%. Oznacza to, że tereny uprzednio zajmowane przez lasy i systemy trawiaste zostały zajęte przez tereny rolnicze. Przeprowadzone badania sugerują, że należy zwrócić szczególną uwagę na szybkie zmiany pokrycia powierzchni terenu, aby utrzymać stabilność i trwałość ekosystemu.

Słowa kluczowe: analiza obrazów, analiza zmian, GIS, teledetekcja, użytkowanie i pokrycie terenu 